\title{
Book Review: GABRIEL, Gottfried and SCHLOTTER, Sven, Frege und die kontinentalen Ursprïnge der analytischen Philosophie (Münster, Mentis, 2017, 251 pages)
}

\author{
Mario Porta \\ Pontificia Universidade Católica de São Paulo \\ Department of Philosophy \\ São Paulo, SP \\ Brazil \\ mariopor@pucsp.br
}

Article info

CDD: 193

Received: 19.03.2018; Accepted: 20.03.2018

DOI: http://dx.doi.org/10.1590/0100-6045.2018.V41N1.MP

Keywords:

Filosofia

Neo-Kantianism

Frege

\section{ABSTRACT}

A review of the book by Gottfried Gabriel and Sven Schlotter Frege und die kontinentalen Ursprünge der analytischen Philosophie (Münster, Mentis, 2017)

\section{Introduction}

The purpose of Frege und die kontinentalen Ursprünge der analytischen Philosophie (Frege and the continental sources of Analytic philosophy) by Gottfried Gabriel and Sven Schlotter is to fill an interpretative gap in the clarification of Frege's ties with his time (p. 1). Performing this task is not merely of historical interest, but is an indispensable element for an adequate systematic understanding of Frege's thought (p. 10). Ignorance of the context is the basis of the standard view, instilled by Dummett, which views Frege as a philosopher of language. In this sense, the principal result of Gabriel and Schlotter's investigation is to change this image of Frege by showing that his interest was principally epistemological, and that from there, his thought consequently necessarily

Manuscrito - Rev. Int. Fil. Campinas, v. 41, n. 1, pp. 185-196, jan.-mar. 2018. 
developed into logic and philosophy of language. It is, then, a matter of demonstrating Frege's ties with his philosophical-historical setting and of doing so, not in some generic way, but by documenting the unequivocally made assertions by means of concrete quotations.

Gabriel and Schlotter's work, however, extends beyond the limits of a reinterpretation of Frege's ideas on a historical-philosophical basis to present itself as a paradigm of a new way of considering the relationship between Analytic and Continental philosophy which, instead of emphasizing an absolute break between the two, stresses the continuity of the former with respect to the latter and, in so doing, the continental roots of Analytic philosophy (p. 10, p. 13). In this sense, their book about Frege must be seen as part of a far-reaching movement which extended to Wittgenstein and Carnap.

\section{A. Exposition ${ }^{1}$}

\section{The continental roots of Fregean logic}

Gabriel and Schlotter underscore the connections between Fregean logic and traditional logic, demonstrating that there has been a steady evolution in Germany since Kant's time (p. 10) and punctiliously laying bare the sources of certain fundamental Fregean ideas (p. 66ff.).

One of the main questions about logic which has arisen since Kant's time due to Hegel's having expounded on it is whether this discipline is merely formal, or whether it is material (and, possibly, metaphysical) in nature. Regarding this question, a controversy referred to as "the logical question" ("die logische Frage"), in which a good number of XIXth century German logicians took part, arose between Trendelenburg and Herbart. This controversy would prove decisive for the Fregean idea of logic, which displays evidence of strong Trendelenburgian inspiration and leans toward a material conception of logic

\footnotetext{
${ }^{1}$ In my exposition, I have slightly changed the order of Gabriel and Schlotter's text dealing with the philosophy of language as a continuation of logic and before to theory of knowledge. In it, Chapters 1 and 2 deal with logic, whereas Chapters 3, 5, 6 deal with theory of knowledge and inserted in between the two is Chapter 4, which deals with philosophy of language. Chapter 8 , finally, deals with the final stage of Frege's thought.
}

Manuscrito - Rev. Int. Fil. Campinas, v. 41, n. 1, pp. 185-196, jan.-mar. 2018. 
(even if Frege did not on account of this subscribe to the thesis of the partial or total identity of logic and metaphysics). Logic was not, then, for Frege, merely "formal," but had its own content, dealing with specific objects. Without this, there would be no possibility of "logicism" (p. 95).

Other relevant areas in which Fregean conceptions take up, or are inspired by, ideas present in the German logicians of the XIXth century, are:

a. the idea of a Begriffschrift (which had originated Leibniz' work and came to Frege via Trendelenburg; pp. 29ff.);

b. aspects of the intensional conception of the concept as function and, especially, an organic model of the formation of concepts and of logic itself as a whole (Trendelenburg; p. 34);

c. the relationship between logic and arithmetic (Lotze; pp. 37f.);

d. the existential interpretation of the forms of Aristotelian judgment, which derived from criticism of the square of opposition of traditional immediate inferences (Herbart, Sigwart; pp. 58ff., 61);

e. the discussion of the Kantian classification of judgments, including the problem of its completeness, of the adequacy of its subdivisions and the homogeneity of the criteria of classification (p. 7). The result would be a new arrangement of the forms of judgment based on a clear distinction between the act of judging and the content judged (Herbart). Placing the quality before the other forms leads to the thesis that the distinction between affirmation and negation is the only one essential for the judgment as such, given that all the others are linked to the content (Herbart, Brentano, Bergmann, Windelband). Frege continued along these lines but reduced affirmation and negation to a single act, recognition (Anerkennung), referring the latter to the content. All the other forms of judgment are interpreted by Frege as forms of content, not of act;

f. the first steps taken towards questioning the properly logical nature of the subject-predicate structure (Lotze, Sigwart) which, nevertheless, would consequently be developed by Frege alone (p. 77f.);

Manuscrito - Rev. Int. Fil. Campinas, v. 41, n. 1, pp. 185-196, jan.-mar. 2018. 
g. the reference of particular judgments to existential judgments and the linking of the latter to numerical attributions (Herbart; p. 64);

h. the epistemological interpretation of the modalities of judgments (pp. 80, 89).

\section{Philosophy of language}

Frege took up the tradition of philosophy of language which already existed in Germany and dated back to Herder (pp. 130ff.), the points of contact with Lotze's and Liebmann's ideas, which coincide in places, including in the terminology used, being of particular relevance (p. 137).

If Gabriel and Schlotter's main line of interpretation consists of bringing out the centrality of the theses relative to philosophy of language, showing its dependence on epistemological questions, then this is manifested paradigmatically in two points:

i. Frege recognized the existence of thinking that could not be reduced to language and emphasized the need of categorial clarification in philosophy, which imply a fight against language taking place within language itself (p. 130);

j. Frege's most important contribution to the philosophy of language, namely, the distinction between sense and reference, is nothing but a semantic reformulation of an epistemic thesis, whose origins are found in the tradition of Leibnizian perspectivism which came to Frege via Lotze (p. 145). Already in Lotze as well, the distinction between sense and reference is linked to the finding that, while being formally synthetic, arithmetical statements possess identical content. What for Lotze was a point of departure turned into Frege's ultimate objective, in other words, the grounding of the cognitive value of such statements (p. 141). But not only in Lotze, but also in Sigwart, do Gabriel and Schlotter detect preparatory stages of Frege's distinction between sense and reference based on considerations about the different forms of cognitive access to the same object or on the cognitive value of identity 
judgments as recognition of what is the same in what is different ( $\mathrm{p}$. 143).

\section{Theory of knowledge}

\subsection{The concept of truth as value}

The concept of value in the Fregean term "truth-value," generally interpreted as being analogous to the mathematical concept of the value of a function, must be understood in a fully axiological sense (p. 160). Frege himself referred to the relation existing between truth as value and ethical and esthetic values.

Frege's treatment of the subject of truth coincides in obvious ways with the ideas of the members of the Baden school, something which is not only expressed in a negative way in the criticism of the correspondence theory of truth, but also in a positive way in the value-theoretical conception of truth inherited from Lotze in which the notion of recognition (Anerkennung) plays a fundamental role). Truth, Windelband told us, is what is recognized in judgments, and judgments what the truth recognizes (p.159). Having said that, the concept of recognition (Anerkennung), refers linguistically to a normative idea of value: values are objects of recognition. As in Windelband, Frege's theory of recognition of truth in judgments (Anerkennungstheorie) involves two phases, the separation between assertive force and the judgeable propositional content, on the one hand, and, on the other hand, an affirmation of this content which must be understood in a value-theoretical sense as the attribution of a truth-value (p. 165).

4.2. The transcendental-pragmatic grounding of our acceptance of logical laws. The epistemological status of logical laws.

Frege accepted different modes of justification, proof or logic demonstration (Beweis) and grounding (Begründung), the former being a matter for logic, the latter for theory of knowledge. The main point of this distinction is that Frege accepted modes of justification which are not strictly speaking 
logical. Without them, we could not, strictly speaking, talk of a grounding of the logicist thesis in Frege.

At first, it may have seemed that in Frege the basic logical laws, which obviously cannot be deduced without circularity, or are not justifiable in any way, or can only refer back to their own self-evidence (something which is at odds with his thesis of the relativity of the axioms). There is, however, another way of justifying basic logical laws, which certainly does not account for their inherent necessity, but rather of our need to recognize them as such (pp. 116117). This mode of justification, which Gabriel and Schlotter call "transcendental-pragmatic", is clearly parallel to that developed by Windelband (pp. 106-107). Indeed, Frege and Windelband coincide both in their assumptions (distinction between proof and grounding) and in what is proved (our recognition), and in the (essentially "teleological") mode of proof (pp. 106107).

With the distinction between proof and grounding, the analytic-synthetic and a priori - a posteriori distinctions and, on the basis of this, the differences between geometry and arithmetic enter in. It is interesting how Gabriel and Schlotter show how Frege's position draws near that of Liebmann when it comes to geometry (p. 96).

\subsection{Transcendental Platonism}

While Frege and neo-Kantianism share what we might call a transcendentalpragmatic grounding of logical laws, both also share, and as something encompassing it, a basic epistemological position which Gabriel and Schlotter call "transcendental Platonism." Transcendental Platonism stands in contrast to ontological Platonism (which asserts the being-in-themselves of transcendental objects or entities in another realm different from the empirical realm) in order to - taking up again Lotze's interpretation of the Platonic theory of Ideas, according to which they do not exist, but are valid - apply the notion of validity (Geltung) to the determination to the transcendental mode of existence (p. 195).

With respect to Windelband, but in theory valid in a generic way for neoKantianism as a whole, Gabriel and Schlotter cite texts in support of their thesis asserting that the transcendental principles which present themselves to 
us as duties (Sollen) are based on validity-in-itself (p. 303). ${ }^{2}$ The validity-in-itself of a proposition is the basis of our taking it as true (Fürwabrbalten) not, on the contrary, our taking it as true the basis of its validity (p. 306).

However, while in order to prove that Windelband's Platonism is not ontological but transcendental, Gabriel and Schlotter appeal to those texts in which the founder of the Baden School, in one way or another, refer to Lotze's thesis that values do not exist, but are valid, in order to prove the same thesis with respect to Frege, they appeal to texts in which Frege referred to the objectivity of numbers, not to a being-in-itself independent of knowledge, but to reason (Vernunft) as a faculty of knowledge (Erkenntnisvermögen) (p. 172) and/or to the "existence of intersubjective cognitive units" (p. 165).

\section{Frege's interest in metaphysics}

Gabriel and Schlotter assert that Frege's logicist project is fundamentally metaphysically motivated (pp. 167, 172). However, the term 'metaphysical' already has two meanings in Kant, namely, as a synonym for a priori knowledge of reason and as a synonym for a priori knowledge of transcendental objects. This gives Gabriel and Schlotter's thesis two possible meanings, since the difficulties in grounding it in each one of them are clearly different. With respect to the first meaning, it is clear that, to the extent that Frege admits informative analytic knowledge or the possibility of a priori access to nonempirical objects, for him, mathematics arrives at a type of knowledge that Kant considered impossible in metaphysics (pp. 174-175. Cfe. Frege: GA, \89). With respect to the second meaning, however, there is really nothing obvious about Gabriel and Schlotter's thesis. Precisely for that reason, it is of interest to pay particular attention to their argumentation, which turns on demonstrating, on the one hand, that Frege explicitly placed his logicist program within the framework of opposing worldviews and, on the other hand, that he observed that deciding between them essentially had to go by way of treating the problem of infinity in mathematics, being radically at odds Cantor in the matter (p. 189. Cfe. Frege: NS, p. 272).

${ }^{2}$ Indeed, Frege made a similar distinction in differentiating between the two meanings of the term 'law.'

Manuscrito - Rev. Int. Fil. Campinas, v. 41, n. 1, pp. 185-196, jan.-mar. 2018. 
It is important to note that the 1915 text in question shows that the metaphysical needs, that initially tried to be satisfied by the logicist program of numbers as objects of reason, was now oriented in another direction, but remained. One of the basic motivations behind the grounding of arithmetic in geometry was in the fact that infinity could be recognized in the strict sense.

\section{Consideration of the final stage of Frege's thought}

Gabriel and Schlotter's consideration of Frege's interest in metaphysics is an example of their tendency to call attention to the existence in Frege's thought of permanent convictions which survive the failure of his logicist program and later assume a new form. As a second element along these lines, it is worth mentioning Frege's opposition to formalism and his conviction that numbers are objects, which is also at the basis of his project to ground arithmetic in geometry. The turn to geometry seeks, then, to secure the idea of numbers as objects no less that the thesis of infinity does.

Along the same lines, Gabriel and Schlotter's observation points to the fact that in the final stage of Frege's thought, his ties with neo-Kantianism grew stronger, his actual interaction with it being documentable, on the one hand, as well as a significant reception by neo-Kantians, on the other. Meriting special attention among such interactions is the relationship of Frege's term and concept of "third realm" (drittes Reich) with its neo-Kantian context, with Simmel and Münch and Hirzel especially (p. 187), as well as the documented disagreement with Bauch as the background for Frege's essay "Negation."

\section{B. Critical Discussion}

In disagreement to what is usually the case among many Analytic philosophers, I recognize the value of Gabriel and Schlotter's perspective and the relevance of their endeavor. I believe it necessary, however, to make some points with respect to what they have achieved in the hoping in the final analysis but to contribute to it.

Even though Gabriel and Schlotter have made a substantial contribution to reconstructing the context of Frege's thought and his actual interactions (furthering investigation into the subject significantly beyond Hans Sluga's

Manuscrito - Rev. Int. Fil. Campinas, v. 41, n. 1, pp. 185-196, jan.-mar. 2018. 
work), this perspective is far from having been exhausted, for they not only leave out of consideration some authors expressly cited by Frege himself (such as, for ex., Grassman and Fischer), but by focusing one-sidedly on Frege's relationship to the neo-Kantianism of Baden, they almost totally overlook Frege's relationship with Brentano's school (Stumpf, Marty, Kerry, Husserl) which, however, constitutes another basic element for reconstructing Frege's philosophical horizon overall, since it is no less a matter of that other major school of the time.

The reference to a certain one-sidedness in the choice of the sources considered warns us about something else, namely that, although Gabriel and Schlotter have shown important and interesting areas of contact between Frege and neo-Kantianism, they do not take into consideration at the same time and with equal emphasis the differences between the two, something which, if actually done would certainly provide a more nuanced view. From this perspective, the following aspects seem to me to be relevant:

a. Certainly the rejection of any ontological or ontologizing interpretation is present both in Lotze's Platonism and in that of the neo-Kantians. However, the mere ontological Platonism - transcendental Platonism alternative does not account here for the possible variants and conceals decisive differences. This situation ends up being extremely compromising when it comes to Frege. Even though he may not have been an ontological Platonist that does not mean that he was then a transcendental Platonist.

b. Regarding Fregean abstract objects, both extensional and intensional, Gabriel and Schlotter time and again find that there is an ontologizing tendency in Frege which is foreign to the neo-Kantians. But, is not this precisely the sign that Fregean Platonism is not transcendental?

c. The same question can ultimately be considered from another point of view. How is one to reconcile Frege's metaphysical motivations in the two senses mentioned with a consistently neo-Kantian standpoint? For a neo-Kantian there can neither be abstract objects, nor a priori knowledge of abstract objects, yet the transcendental method requires that the only knowledge a priori possible be knowledge of the conditions of possibility of empirical knowledge.

Manuscrito - Rev. Int. Fil. Campinas, v. 41, n. 1, pp. 185-196, jan.-mar. 2018. 
d. But, it will be said: Have not Gabriel and Schlotter proved the existence of a transcendental-pragmatic grounding of logic as much in Frege as in neo-Kantianism? I do not want to deny this, but rather call attention to the fact that Windelband's logic is transcendental logic too, while that of Frege is only general logic (even when certainly nonformal). More concretely, while the transcendental grounding in Windelband is paradigmatically oriented toward the principle of causality, in Frege it is oriented toward the principle of identity.

e. Elaborating therefore on the differences between Frege and the neoKantians indicated, one finds that, far from totally ignoring them, Gabriel and Schlotter in a certain way take them into consideration and, in such cases, tend to favor neo-Kantianism, so that ultimately they end up offering us not a neo-Kantian Frege strictly speaking, but actually a Frege improved, corrected through the lenses of neoKantianism.

f. Presented with such a situation, it seems to me opportune to call attention to the possibility of a different perspective, which does not understand Frege in terms of neo-Kantianism but, in a certain sense and in, so to speak, a schematic way, neo-Kantianism through Frege. An impartial interpretation of the relationship between Frege and neoKantianism must ultimately account for the fact that Analytic philosophy developed out of the former and not out of the latter and that, overall, it brought the emergence of a paradigm that also contributed to the decline of neo-Kantianism. The decisive difference between Frege and neo-Kantianism seems to me to be rooted in the fact that the reflection of the latter exclusively takes its orientation from the concept of validity (Geltung), while the former introduces the fundamental distinction between sense and truth-value, which is completely absent in the neo-Kantian scheme of things. With this, the problem of objectivity splits into two clearly different questions, that about the objectivity of the truth-value and that about the objectivity of sense (being that each one of them is, in turn, subject to a noetic variant and noematic variant). One sign of the pertinence of what has been said is the characteristic difference between the two of them in the fight against psychologism which, while being almost exclusively 
epistemological (and, in general, axiological), in the neo-Kantians, is also essentially semantic in Frege (and later in Husserl). The very material brought up by Gabriel and Schlotter concerning Bauch as Frege's interlocutor in "Negation" confirms this idea. They rightly find that there are two fundamental areas of disagreement between Bauch and Frege: the existence or not of false thoughts and the status of negation. Fine, I submit that these two differences are not unconnected and refer to an even more fundamental one, namely, the presence in Frege's thought and the absence in Bauch's of a clear distinction between sense and truth-value. Precisely because of this, Bauch is obliged to say that, being worthless, false thoughts have no existence in-themselves, but solely exist in the subject thinking them ${ }^{3}$. This difference between Frege and Bauch, is a difference that can already be traced back to Windelband, for whom, even when values-inthemselves certainly exist, nothing suggests that he also admitted an existence in-itself of anything similar to a Fregean thought (Gedanke) $)^{4}$. In Windelband, truth-bearers seem to be simply connections of representations (Vorstellungsverbindungen) (NN, p. 74).

g. We already observe that there is an important difference in the way in which Gabriel and Schlotter prove that Frege's basic epistemological position can be characterized as transcendental Platonism. For a neoKantian like Windelband, the concept of validity (Geltung) is an ultimate concept not definable subsequently and possesses a supra-objective character and a supra-subjective character in equal measure since it is the basis of the subject-object distinction itself. Gabriel and Schlotter, however, assimilate validity in Frege to reason (Vernunft) and reason, in turn, to intersubjectivity. With this, they seem to have been remaining faithful, more so than is desirable or necessary, to an interpretation

\footnotetext{
3 "Der falsche Satz $3+2=6$ hat gewiss eine Wirklichkeit jedesmal, wenn er von einem denkenden Subjekt gedacht oder ausgesprochen wird. Aber unabhängig von seinem wirklichen gedacht oder ausgesprochen werden hat er keinen Bestand, wie ihn die Gleichung $3+2=5$ durch ihre Geltung hat." Bauch: Wahrheit und Richtigkeit, p. 47 (emphasis added).

${ }^{4}$ The case of Rickert from 1907 on merits special consideration, not having to overlook his discussion with Lask, influenced by Husserl.
}

Manuscrito - Rev. Int. Fil. Campinas, v. 41, n. 1, pp. 185-196, jan.-mar. 2018. 
along the lines of Sluga's, which is conducted within the distinction between transcendental idealism and Platonic idealism and which, on the one hand, links transcendental idealism to validity, on the other, however, continues to think that the notion of a "transcendental subject" is in some way essential to such idealism. This, however, which can rightly be maintained with respect to variants of transcendental idealism from Kant to Husserl, via Fichte, does not rightly hold for neo-Kantianism.

To conclude, let me say that, in spite of some possible improvements of the kind I have noted, Gabriel and Schlotter's investigation unquestionably constitutes an indispensable frame of reference for the subjects it treats, and any subsequent study of them must take it into account and will only be of real value if argued on the basis of it.

\section{References}

Frege, GotTlob. Die Grundlagen der Arithmetik. Eine logisch mathematische Untersuchung über den Begriff der Zahl. Hamburg: Meiner, 1988. (GA)

Nachgelassene Schriften. Unter Mitwirkung von Gottfried Gabriel und Walburg Rödding, ed. by Hans Hermes, Friedrich Kambartel and Friedrich Kaulbach. Hamburg: Felix Meiner Verlag, 1969. (NS)

LOTZE, HeRmann. Grundrüge der Religionsphilosophie. $2^{\text {nd }}$ ed. Leipzig: Verlag von S. Hirzel, 1889. (GRel)

Windelband, Wilhelm. Die Prinzipien der Logik. In: Windelband, Wilhelm and Ruge, A. (eds.) Encyclopädie der philsophischen Wissenschaften. Tübingen 1912. Vol. 1. pp. 1-60 (PL)

Normen und Naturgesetze. In Windelband, Wilhelm. Präludien. Aufsätze und Reden zur Philosophie und ihrer Geschichte. Vol. 2. Tübingen, 1884. $9^{\text {th }}$ ed. 1924. II, pp. 59-98 (NN)

\section{(cc) $\mathrm{EY}$}

Manuscrito - Rev. Int. Fil. Campinas, v. 41, n. 1, pp. 185-196, jan.-mar. 2018. 